\title{
Particle size and feed form in broiler diets: impact on gastrointestinal tract development and gut health
}

\author{
F. ZAEFARIAN*, M.R. ABDOLLAHI and V. RAVINDRAN \\ Institute of Veterinary, Animal and Biomedical Sciences, Massey University, Private \\ Bag 11 222, Palmerston North 4442, New Zealand \\ *Corresponding author: F.Zaefarian@massey.ac.nz
}

The importance of feed particle size, as a tool to optimise the utilisation of feed and improve production efficiency in broilers, has attracted increased attention in recent years. Particle size reduction is widely believed to enhance the access of digestive enzymes to substrates because of the increased surface area of feed particles. Fine particles can negatively affect the development of fore-gut (proventriculus and gizzard), which plays an important role in intestinal health and nutrient utilisation. A well-developed fore-gut can be achieved by feeding coarse particles which is associated with improvements in gut motility and health. However, the results of studies considering the effect of feed particle size on upper gastrointestinal tract development have been inconclusive, because of the confounding effects of feed form (mash vs. pellets). Feed particle size influences the development of gastrointestinal tract and bird performance to a greater extent when the broilers are fed mash than pelleted diets. Particle size-reducing properties of the pelleting process may result in suboptimal gizzard development and changes in the intestinal morphology and microbiota profile.

Keywords: particle size; pelleting; gastrointestinal tract; intestinal morphology; intestinal microbiota profile; broilers

\section{Introduction}

It is generally believed that fine grinding enables digestive secretions better access to substrates, improving digestion and absorption and subsequently increasing the growth efficiency (Behnke, 2001). However, it is increasingly recognised that the broilers may have a requirement for a certain degree of physical structure in their feed to meet their innate feeding behaviour (Ferket and Gernat, 2006). In recent years, the use of dietary structural components, such as coarse particles and whole grains in poultry diets, have attracted considerable attention due to their effects on the development and functionality of the gizzard (Svihus et al., 2002). The beneficial effects of such practices may extend to 
a favourable influence on intestinal morphology and functionality (Nir et al., 1994a; Amerah et al., 2007a; 2007b) and microbiota profile (Engberg et al., 2004). However, published data on the effects of particle size on the gastrointestinal tract (GIT) parameters of broilers have been contradictory due largely to the confounding effects of feed physical form (mash vs. pelleted diets), with the impact of particle size being more pronounced in mash feeds than in pelleted or crumbled feeds (Svihus et al., 2004a; Péron et al., 2005; Amerah et al., 2007b). The particle size effect is exacerbated during pelleting, which further reduces the feed particle size and may equalise the differences in particle size distribution (Svihus et al., 2004b; Amerah et al., 2007b; Abdollahi et al., 2011). It has been reported that in birds fed pelleted diets, consisting of finely ground dietary ingredients, the upper regions of the gut may no longer be functional in the terms of mixing, grinding and may cause reverse peristalsis contractions (Cumming, 1994; Duke, 1994).

Several extensive reviews are available on the influence of particle size and feed form on the nutrient utilisation, performance and development and health of GIT of broilers (Amerah et al., 2007a; Svihus, 2011; Abdollahi et al., 2013b). The current review focuses on the physiological consequences of particle size and pelleting on GIT parameters, intestinal morphology and microbiota profile.

\section{Effect of feed particle size on GIT development}

Particle size has been reported to influence nutrient utilisation, growth performance, gizzard development and feed passage rate in broilers (Gabriel et al., 2003a; 2003b; Amerah et al., 2007a, 2008a; 2008b). The effect of particle size has been studied in wheat (Gabriel et al., 2006; Amerah et al., 2008a; 2008b), maize (Zang et al., 2009; Jacobs et al., 2010; Pacheco et al., 2013; Xu et al., 2015a; 2015b; 2015c) and soybean meal (Pacheco et al., 2013).

The influence of feed particle size on gizzard development is well documented (Table 1). The gizzard has a remarkable ability to grind the feed to a consistent particle size (Hetland et al., 2004). Early work of O'Dell et al. (1959) showed that birds fed purified diets containing fine particles had an enlarged proventriculus and smaller gizzards compared to those containing large particles. It was found that the diets with fine particles moved through the GIT more rapidly (135 vs. 165 minutes) and the proventriculus of birds fed fine diets was filled with fluid rather than with feed. The birds were observed to drink more water, probably to aid in the swallowing and there was a tendency toward a pendulous crop. 
Feed technology and gastrointestinal tract: F. Zaefarian et al.

Table 1 Influence of feed particle size on the relative weight ( $\mathrm{g} / \mathrm{kg}$ body weight) of GIT $^{1}$ segments in broilers.

\begin{tabular}{|c|c|c|c|c|c|}
\hline \multirow[t]{2}{*}{ GIT segments } & \multirow{2}{*}{$\begin{array}{l}\text { Grain } \\
\text { type }\end{array}$} & \multicolumn{3}{|c|}{ Feed particles } & \multirow[t]{2}{*}{ Reference } \\
\hline & & Fine & Medium & Coarse & \\
\hline Pancreas & Wheat & 1.9 & - & 1.9 & Engberg et al. (2002) \\
\hline Gizzard & & 14.6 & - & 15.5 & \\
\hline Gizzard & Wheat & 14.9 & 16.2 & 17.5 & Svihus et al. $(2004 b)^{2}$ \\
\hline Gizzard & Wheat & 13.0 & - & 15.0 & Péron et al. (2005) \\
\hline Duodenum & & 12.0 & - & 13.0 & \\
\hline Jejunum & & 20.0 & - & 20.0 & \\
\hline Ileum & & 16.0 & - & 15.0 & \\
\hline Crop & Wheat & - & 3.20 & 3.00 & Amerah et al. (2007b) \\
\hline Proventriculus & & - & 5.52 & 5.30 & \\
\hline Gizzard & & - & 16.4 & 15.7 & \\
\hline Duodenum & & - & 6.3 & 6.0 & \\
\hline Jejunum & & - & 13.2 & 12.2 & \\
\hline Ileum & & - & 9.1 & 8.7 & \\
\hline Caeca & & - & 1.9 & 1.9 & \\
\hline Crop & Wheat & 3.04 & - & 3.05 & Amerah et al. (2008a) \\
\hline Proventriculus & & 3.84 & - & 3.95 & \\
\hline Gizzard & & 9.03 & - & 10.0 & \\
\hline Duodenum & & 5.12 & - & 5.20 & \\
\hline Jejunum & & 11.6 & - & 11.7 & \\
\hline Ileum & & 7.90 & - & 7.60 & \\
\hline Caeca & & 1.48 & - & 1.63 & \\
\hline Pancreas & Wheat & - & 3.33 & 3.34 & Amerah et al. (2008b) \\
\hline Gizzard & & - & 17.9 & 19.2 & \\
\hline Duodenum & & - & 5.14 & 5.44 & \\
\hline Jejunum & & - & 11.4 & 11.1 & \\
\hline Ileum & & - & 7.75 & 7.57 & \\
\hline Caeca & & - & 1.70 & 1.70 & \\
\hline Gizzard & Maize & 9.10 & - & 10.4 & Huang et al. (2006) \\
\hline Caeca & & 1.40 & - & 1.45 & \\
\hline Gizzard & Maize & 15.1 & 16.0 & 18.1 & Parsons et al. (2006) \\
\hline Crop & Maize & 2.90 & - & 3.30 & Amerah et al. (2008a) \\
\hline Proventriculus & & 4.62 & - & 4.28 & \\
\hline Gizzard & & 9.40 & - & 12.6 & \\
\hline Duodenum & & 5.25 & - & 5.24 & \\
\hline Jejunum & & 10.8 & - & 10.5 & \\
\hline Ileum & & 7.50 & - & 6.90 & \\
\hline Caeca & & 1.59 & - & 1.42 & \\
\hline Proventriculus & Maize & - & 4.47 & 4.56 & $\begin{array}{l}\text { Amerah and } \\
\text { Ravindran } \\
(2009)\end{array}$ \\
\hline Gizzard & & - & 19.8 & 20.7 & \\
\hline Small intestine & & - & 19.02 & 19.09 & \\
\hline Caeca & & - & 1.52 & 1.50 & \\
\hline Pancreas & Maize & 2.16 & - & 2.37 & Rougière et al. (2009) \\
\hline
\end{tabular}


Feed technology and gastrointestinal tract: F. Zaefarian et al.

Table 1 Continued

\begin{tabular}{|c|c|c|c|c|c|}
\hline \multirow[t]{2}{*}{ GIT segments } & \multirow{2}{*}{$\begin{array}{l}\text { Grain } \\
\text { type }\end{array}$} & \multicolumn{3}{|c|}{ Feed particles } & \multirow[t]{2}{*}{ Reference } \\
\hline & & Fine & Medium & Coarse & \\
\hline Proventriculus & & 4.36 & - & 4.64 & \\
\hline Gizzard & & 14.7 & - & 18.9 & \\
\hline Duodenum & & 8.75 & - & 8.55 & \\
\hline Jejunum & & 12.5 & - & 12.8 & \\
\hline Ileum & & 9.48 & - & 8.84 & \\
\hline Proventriculus & Maize & 2.38 & - & 2.27 & $\mathrm{Xu}$ et al. (2015a) \\
\hline Gizzard & & 8.11 & - & 9.21 & \\
\hline Jejunum & & 12.56 & - & 11.27 & \\
\hline Ileum & & 10.88 & - & 10.41 & \\
\hline Proventriculus & Maize & 2.26 & - & 2.12 & $\mathrm{Xu}$ et al. (2015b) \\
\hline Gizzard & & 9.52 & - & 10.97 & \\
\hline Pancreas & Maize & 2.73 & 2.90 & 2.82 & $\begin{array}{l}\text { Naderinejad et al. } \\
\text { (2016) }\end{array}$ \\
\hline Proventriculus & & 3.91 & 4.13 & 3.87 & \\
\hline Gizzard & & 12.9 & 14.9 & 15.0 & \\
\hline Small intestine & & 22.8 & 23.1 & 22.1 & \\
\hline Caeca & & 3.22 & 3.35 & 3.20 & \\
\hline
\end{tabular}

${ }^{1}$ GIT, Gastrointestinal tract

${ }^{2}$ Roller mill grinding

Moore (1999) reported that, in geese, the folds of pylorus and its small opening play a sieving role which does not allow very large particle to pass through during contractions. Hetland et al. (2002) similarly found in broilers that, regardless of the original feed structure, the majority of particles were smaller than $0.04 \mathrm{~mm}$ in size when the digesta passed beyond the gizzard. According to Nir and Ptichi (2001), the relative gizzard weight was positively correlated to feed particle size when the diets were in mash form. In birds fed mash diets with coarsely ground particles, digesta were retained for longer in the gizzard along with greater gizzard development (Nir et al., 1994a; Hetland and Svihus, 2001; Engberg et al., 2002). Nir et al. (1994a) reported that when day-old chicks were fed medium and coarse maize particles, gizzard weight increased by 26 and $41 \%$, respectively, compared to those fed fine particles. Kilburn and Edwards (2004) stated that larger particles were retained longer, allowing more time for nutrient digestion and absorption. These benefits were reduced when the diet was fed in pelleted or crumbled form, presumably as a result of concomitant degradation of larger particles during the pelleting process. Charbeneau and Roberson (2004) and Jacobs et al. (2010) similarly reported an increase in gizzard weight as particle size of dietary maize increased. Pacheco et al. (2013) evaluated the effect of soybean meal and maize particle sizes on gizzard weight and found that the maize particle size had a greater influence on gizzard size than did soybean meal particle size. Xu et al. (2015b) found that relative proventriculus weight was decreased and the relative gizzard weight was increased at 49 days of age by the inclusion of $500 \mathrm{~g} / \mathrm{kg}$ coarse maize. It was suggested that this relative relationship between gizzard and proventriculus weight may be due to the fact that broilers may have adjusted their mechanical and enzymatic digestive functions according to the physical structure of feed. Increased gizzard weight due to increased maize particle size is a logical consequence of 
enhanced mechanical grinding activity (Dahlke et al., 2003; Parsons et al., 2006). Naderinejad et al. (2015) reported that, regardless of feed form, medium and coarse grinding of maize increased the gizzard weight compared to fine grinding. In contrast, $\mathrm{Xu}$ et al. (2015c) reported that relative gizzard weight was not affected by percentage of coarse maize (up to $500 \mathrm{~g} / \mathrm{kg}$ ) in crumble diet, while it increased in a linear manner with increasing of coarse maize inclusion in the mash diet.

Nir et al. (1995) suggested that coarser particles are better suited for poultry because of their stimulating effect on the gizzard size and gut motility. The stimulation of gut motility is an important effect of coarse particles (Sacranie, 2006) and has been hypothesised to improve intestinal strength due to greater muscular activity related to reverse peristalsis (Xu et al., 2015a).

Higher grinding activity in the gizzard increases the size of the gizzard muscles, which are myelinated and have a koilin layer (Preston et al., 2000; Svihus, 2011; 2014). Generally, a large and well-developed gizzard is associated with its musculature and increased grinding activity (Nir et al., 1994a; 1994b; Amerah et al., 2007a; 2007b; Svihus, 2011), increased pancreatic enzyme secretion through increased release of cholecystokinin (Svihus, 2011) and improved GIT motility (Ferket, 2000; GonzálezAlvarado et al., 2008), with the overall result of improved nutrient utilisation. Garcia et al. (2007) reported that the increase in gizzard/intestine weight ratio was accompanied by an increase in apparent metabolisable energy (AME) values. They suggested that this ratio could be an efficient mean for predicting variations in nitrogen-corrected AME responses observed with xylanase.

Three distinct sites of reverse peristalsis can be observed in the GIT of birds (Duke, 1982): i) gastric reflux transferring the digesta from gizzard to proventriculus via gastroduodenal contractions (two to four cycles per min), ii) the small intestinal reflux, that transfers digesta from the duodenum and jejunum into the gastric area (about four times per hour) and increases the digesta retention time, iii) cloaca-caecal reflux, which transfers urinary nitrogen to the caeca via the colon particularly when fed low-protein diets (Karasawa, 1999). A well-developed gizzard generates stronger reverse peristalsis contractions and increases proteolysis by pepsin, trypsin and other endogenous proteases in the small intestine (Ferket, 2000). Gabriel et al. (2003a) reported that large feed particles enhanced pepsin activity in the proventriculus.

When broilers were fed coarse structured feeds, in comparison to finely ground feeds, lower pH was recorded in the gizzard (Nir et al., 1994a; Engberg et al., 2002; JiménezMoreno et al., 2013) and proventriculus (Nir et al., 1995). Jiménez-Moreno et al. (2009; 2013) and González-Alvarado et al. (2008) found that inclusion of structural components, such as oat hulls and sugar beet pulp, in mash diets reduced the $\mathrm{pH}$ of the gizzard. The same result was reported by Sacranie et al. (2012) for a mixture of oats and barley hulls. Higher $\mathrm{HCl}$ production as a result of longer retention time of digesta in the gizzard might be the reason for the reduced gizzard pH. However, Naderinejad et al. (2015) reported that gizzard $\mathrm{pH}$ was responsive to particle size only in pelleted maize diets. The lack of gizzard $\mathrm{pH}$ response to particle size in mash diets is in agreement with the findings by Charbeneau and Roberson (2004), Jacobs et al. (2010) and Singh et al. (2014). Naderinejad et al. (2016) found that, although pelleting reduced the proportion of coarse particles, it seemed that a minimum of 40 to $60 \mathrm{~g} / \mathrm{kg}$ coarse particles of $>2$ $\mathrm{mm}$ was sufficient to stimulate secretion of hydrochloric acid and reduce the gizzard $\mathrm{pH}$ to the same level as mash-fed birds.

Feed particle size has also been found to influence GIT segments other than the gizzard, but the results are contradictory. Nir et al. (1994a) reported that, in addition to the gizzard, coarse maize diets increased the relative weights of jejunum, ileum and whole small intestine. Nir et al. (1994b) reported that birds fed sorghum-soybean meal 
mash diets showed hypertrophy of the small intestine compared to pellet diets. In subsequent study, Nir et al. (1995) found no differences in the weight of intestinal segments with maize particle sizes increasing from 0.6 to $2.17 \mathrm{~mm}$. However, Amerah et al. (2007b) reported a reduction in the relative length of all GIT components as wheat particle size increased. A decreased intestinal weight or length may result in improved feed efficiency due to reduced maintenance costs $(\mathrm{Xu}$ et al., 2015a).

Pelleting has been shown in a number of studies to even out the differences in particle size (Svihus et al., 2004b; Péron et al., 2005; Amerah et al., 2007b; Abdollahi et al., 2011), but the beneficial influence of coarse particles might still exist after pelleting.

The study by Nir et al. (1995) showed that the effect of grain particle size was preserved even after pelleting. Naderinejad et al. (2016) reported that coarse grinding of maize, through enhanced gizzard development and functionality, was beneficial to nutrient and energy utilisation and growth performance in broilers fed pelleted diets. Amerah et al. (2007b) concluded that wheat particle size was more critical in mash than in pelleted or crumble diets. Péron et al. (2005) found that pelleting coarse particles with very hard wheat-based diets increased gizzard weights compared to those with fine wheat, which was attributed to the resistance of hard particles to size reduction during the pelleting process. It would appear that the effect of grain particle size in pelleted diets on gizzard development depends on the cereal base used and grain hardness. Moreover, technical parameters of pelleting process, such as pellet diameter and the gap between the rollers and pellet die, may potentially influence the final particle size. A large pellet diameter and an increased gap between the rollers and the die will reduce the grinding of particles in the pellet press.

\section{Effect of feed particle size on gut morphology and microbiota profile}

There have been limited reports on the influence of feed particle size on intestinal morphology and the results are inconsistent. Nir et al. (1994b; 1995) reported that the duodenal villus height increased linearly as the dietary particle size increased. However, Amerah et al. (2007b) reported that villus height, crypt depth, and epithelial thickness in the duodenum were unaffected by maize particle size. Their results were confirmed by Zang et al. (2009). However, Liu et al. (2006) reported that coarse maize inclusion reduced the number of mast cells in the duodenum, jejunum, and ileum as compared with finely ground maize. Xu et al. (2015a) reported that $500 \mathrm{~g} / \mathrm{kg}$ dietary inclusion of coarse maize increased the jejunal tip width and villi surface area, but decreased the thickness of muscularis layer. This finding was considered as a general response of the digestive and absorptive capacity of the proximal small intestine to greater digesta retention time to facilitate greater contact between the nutrients and villi.

A developed gizzard can be regarded as a barrier in preventing pathogenic bacteria from entering the distal GIT (Engberg et al., 2004). However, data on the effects of feed particle size on the intestinal microbiota profile are scanty. Harmful bacteria entering the GIT via the feed have a greater chance of being suppressed in a highly acidic environment. Engberg et al. (2002) stated that an increase in Lactobacilli spp. populations is usually considered to be beneficial to the host because they can prevent colonisation of pathogens such as E. coli. These researchers compared coarse or finely ground mash or pelleted feed and reported that there was an increase in Lactobacilli spp. populations in the caeca when birds were given coarse mash diets, with the lowest counts of lactic acid bacteria being recorded in those given finely ground pelleted diets. Jacobs et al. (2010) observed an increase in Lactobacilli spp. and a decrease in Bifidobacteria spp. 
when birds were fed large maize particles $(1.4 \mathrm{~mm})$ compared to those fed fine maize particles $(0.6 \mathrm{~mm})$.

Singh et al. (2014) fed broilers diets with graded levels of coarse maize $(0,150,300$, $450,600 \mathrm{~g} / \mathrm{kg}$ ) in mash diets and found that the counts of Lactobacillus spp. and Bifidobacteria spp. increased and those of Clostridium spp., Campylobacter spp., and Bacteroides spp. decreased with increasing inclusion levels of coarse maize. In birds fed fine particles, the feed is less exposed to low $\mathrm{pH}$ and proteases in the gizzard, and ingested feed appears more quickly in the duodenum (Hill, 1971). The presence of such undigested material in the upper small intestine may result in aberrant bacterial populations such as Clostridium perfringens, the pathogenic agent of necrotic enteritis, or E. coli, as suggested by Cumming (1994).

The observed particle size effects on gut microbiota profiles may be explained by one or both of the following mechanisms: First, stimulation of gizzard development and increased secretion of hydrochloric acid, reduces the $\mathrm{pH}$ and subsequently has an antimicrobial effect on pathogenic bacteria entering the distal part of GIT (Engberg et al., 2002). Second, competitive exclusion may be promoted by encouraging colonisation of commensal bacteria and thus discouraging colonisation of harmful bacteria (Bjerrum et al., 2005; Santos et al., 2008).

\section{Effect of feed form on GIT development}

Although improved broiler performance is an advantage for pellet vs. mash feeding, there are negative physiological consequences on the development of GIT (Nir et al., 1994a; Engberg et al., 2002; Amerah et al., 2007b; Abdollahi et al., 2011). The birds do not fully develop their upper GIT when highly processed pelleted feeds are used. Nir et al. (1995) reported that pelleting reduced the proventriculus weight and its contents at $21 \mathrm{~d}$ of age, but not during the finisher period (40 d of age). Abdollahi et al. (2011) observed lower relative weights of the proventriculus in pellet-fed birds than those fed mash diets. However, Mirghelenj and Golian (2009) found that the relative weights of crop and proventriculus were unaffected by feed form.

The relative weight of the gizzard has been shown to decrease when birds are fed pelleted rather than mash diets (Table 2). The reduction in the size of gizzard, with pellet feeding, is a logical response to reduced grinding activity as a result of finer particle size caused by the pelleting process (Engberg et al., 2002; Svihus et al., 2004a; Péron et al., 2005; Abdollahi et al., 2011). Pelleting-induced particle size reduction has been suggested as a result of large particles being prone to grinding due to the narrow gap between pellet rollers and the pellet die (Svihus et al., 2004b), and frictional force inside the die itself (Abdollahi et al., 2011). Engberg et al. (2002) reported that pelleting considerably reduced feed particle size and equalised the differences between coarsely and finely ground meals in wheat-based diets. In their study, due to pelleting, the fraction of feed particles with a size of over $1.0 \mathrm{~mm}$ reduced from 262 to $149 \mathrm{~g} / \mathrm{kg}$ in the coarsely ground diet, and from 209 to $135 \mathrm{~g} / \mathrm{kg}$ in the finely ground diet. In agreement, Abdollahi et al. (2011) showed that the passage of diets through the pellet die reduced the proportion of coarse particles over $2.0 \mathrm{~mm}$ and increased the proportion of fine particles less than $0.075 \mathrm{~mm}$. 
Feed technology and gastrointestinal tract: F. Zaefarian et al.

Table 2 Influence of feed form on the relative weight $\left(\mathrm{g} / \mathrm{kg}\right.$ body weight) of GIT $^{\mathbf{1}}$ segments in broilers.

\begin{tabular}{|c|c|c|c|c|c|}
\hline \multirow[b]{2}{*}{ GIT segments } & \multirow[b]{2}{*}{ Grain type } & \multicolumn{2}{|c|}{ Feed form } & \multirow[b]{2}{*}{ Improvement (\%) } & \multirow[b]{2}{*}{ Reference } \\
\hline & & Mash & Pellet & & \\
\hline Pancreas & Wheat & 2.00 & 1.80 & -10.0 & Engberg et al. (2002) \\
\hline Gizzard & & 17.4 & 12.6 & -27.6 & \\
\hline Gizzard & Wheat & 16.2 & 11.8 & -27.2 & Svihus et al. $(2004 b)^{2}$ \\
\hline Crop & Wheat & 3.00 & 3.10 & +3.3 & Amerah et al. (2007b) \\
\hline Proventriculus & & 5.45 & 5.37 & -1.5 & \\
\hline Gizzard & & 21.1 & 11.0 & -47.9 & \\
\hline Duodenum & & 5.90 & 6.40 & +8.5 & \\
\hline Jejunum & & 12.5 & 12.9 & +3.2 & \\
\hline Ileum & & 8.90 & 8.90 & 0.0 & \\
\hline Caeca & & 2.20 & 1.60 & -27.3 & \\
\hline Proventriculus & Wheat & 4.27 & 3.88 & -9.1 & Abdollahi et al. (2011) \\
\hline Gizzard & & 15.2 & 10.3 & -32.2 & \\
\hline Small intestine & & 25.0 & 23.8 & -4.80 & \\
\hline Caeca & & 1.32 & 1.20 & -9.1 & \\
\hline Gizzard & Maize & 11.5 & 8.00 & -30.4 & Huang et al. (2006) \\
\hline Caeca & & 1.25 & 1.60 & +28.0 & \\
\hline Gizzard & Maize & 15.05 & 11.75 & -21.9 & Chewning et al. (2012) \\
\hline Pancreas & Maize & 3.41 & 2.84 & -16.7 & Abdollahi et al. (2013a) \\
\hline Proventriculus & & 4.33 & 3.97 & -8.30 & \\
\hline Gizzard & & 15.9 & 13.4 & -15.7 & \\
\hline Small intestine & & 23.8 & 22.3 & -6.30 & \\
\hline Caeca & & 1.41 & 1.12 & -20.6 & \\
\hline Pancreas & Wheat & 3.12 & 2.37 & -24.0 & Abdollahi et al. (2013a) \\
\hline Proventriculus & & 4.71 & 4.04 & -14.2 & \\
\hline Gizzard & & 15.9 & 10.8 & -32.1 & \\
\hline Small intestine & & 27.7 & 23.8 & -14.1 & \\
\hline Caeca & & 1.54 & 1.25 & -18.8 & \\
\hline Pancreas & Sorghum & 2.86 & 2.88 & +0.7 & Abdollahi et al. (2014) \\
\hline Proventriculus & & 4.35 & 4.30 & -1.1 & \\
\hline Gizzard & & 13.4 & 9.13 & -31.9 & \\
\hline Small intestine & & 24.8 & 25.3 & +2.0 & \\
\hline Caeca & & 1.46 & 1.23 & -15.8 & \\
\hline Pancreas & Maize & 3.01 & 2.63 & -12.6 & Naderinejad et al. (2016) \\
\hline Proventriculus & & 4.23 & 3.72 & -12.1 & \\
\hline Gizzard & & 16.5 & 12.0 & -27.3 & \\
\hline Small intestine & & 22.7 & 22.6 & -0.44 & \\
\hline Caeca & & 3.44 & 3.07 & -10.8 & \\
\hline
\end{tabular}

${ }^{1}$ GIT, Gastrointestinal tract

${ }^{2}$ Roller mill grinding

There appears to be an association between gizzard and pancreatic weights. Liu et al. (2015) reported a positive correlation between relative weight of gizzard and pancreas. Engberg et al. (2002) showed that birds fed pelleted diets had lower pancreas weights 
and pancreatic enzyme (amylase, lipase, and chymotrypsin) activities than those fed mash diets. This finding is consistent with the results of Agah and Norollahi (2008) showing a lower relative pancreas weight in broilers fed pelleted diets compared to those fed mash diets.

Published data on the effects of pelleting on the relative weight and length of small intestine are summarised in Table 2. Nir et al. (1994b) stated that with increasing pelleting percent, relative weight of gizzard, as well as length of jejunum and ileum decreased. Pelleting levels in their study were: 0 (mash), 0.5 (mixture of mash and soft pellets (pelleted once)), 1 (soft pellets), 1.5 (mixture of soft pellets and hard pellets (pelleted twice)) and 2 (hard pellets). Amerah et al. (2007b) and Abdollahi et al. (2011; 2013a) found that relative empty weight of intestinal segments were greater in birds fed mash diets than those fed pelleted diets. Mirghelenj and Golian (2009) showed that pelleting reduced the relative length of caeca. The same result was reported by Abdollahi et al. (2011), who found a heavier caeca weight in mash-fed compared to pellet-fed birds. A lower weight of caeca may cause a higher amount of water being excreted relative to feed intake (Maisonnier et al., 2001). Svihus et al. (2013) stated that feeding pelleted wheat-based diets increased excreta moisture. As recycling and reabsorption of water occurs largely in the caeca and colon, the poor caecal development in birds fed pelleted diets has implications for water loss and conservation.

The $\mathrm{pH}$ along the GIT of birds varies widely. The crop is moderately acidic (5.5), the proventriculus and gizzard are acidic (2.5-3.5) and the intestine is moderately neutral to moderately alkaline (5.0-7.5). It has been shown that gizzard $\mathrm{pH}$ is relatively higher with pelleted diets when compared to mash diets (Engberg et al., 2002; Huang et al., 2006; Frikha et al., 2009: Naderinejad et al., 2016). Recently, Liu et al. (2015) reported a negative correlation $(\mathrm{r}=-0.45)$ between the relative gizzard weight and gizzard $\mathrm{pH}$ and suggested that the consequence of heavier gizzard weight goes beyond grinding activity.

The upper GIT (crop, proventriculus and gizzard) are main sites of action of exogenous enzymes (Selle and Ravindran, 2007). The average digesta retention time in the GIT of birds is short (135 to 280 minutes). As a result, digesta possibly spends only 60 to $90 \mathrm{~min}$ in the upper GIT, which gives only limited opportunity for enzyme action. As pelleting reduces gizzard development, the time feed spends in the upper GIT decreases even more and this can be limiting factor for exogenous enzyme efficiency in pelleted diets. According to Abdollahi et al. (2013a), considering the increased feed intake (up to $27 \%$ ) and decreased gizzard size (up to $32 \%$ ) in pellet-fed birds, the retention time per unit of feed becomes even shorter compared to mash-fed birds. The shorter digesta retention time and an elevated gizzard $\mathrm{pH}$, due to an under-developed gizzard, are possible physiological limits to optimal digestion in pellet-fed birds (Ravindran, 2013).

Amerah et al. (2007b) observed that the pelleting process reduced the size of coarse particles and minimised the differences between the distribution of medium and coarse particles. However, in their study, pelleted diets with coarse particles showed heavier proventriculus and gizzard weights (by 4.9 and 5.6\%, respectively) compared to pelleted diets with medium particle. Increased gizzard weight with medium and coarse grinding of maize in pelleted diets has also been reported by Dahlke et al. (2003) and Naderinejad et al. (2016). As broiler diets are usually pelleted, it would appear that coarse grinding could be beneficial in terms of upper GIT development, depending on the cereal type and grain hardness.

Overall, it is evident that the poor gizzard development in pellet-fed birds is due mainly to the lack of mechanical stimulation by the feed. Pelleting decreases the grinding requirement of the gizzard so that its function is reduced to that of a transit organ (Amerah et al., 2007b). Pellets disintegrate in the crop and pass directly through the 
proventriculus and gizzard to enter the duodenum. This explains the higher digesta dry matter content observed in the upper small intestine (duodenum) of pellet-fed birds (Engberg et al., 2002). A coarse mash diet stays longer in the gizzard, thus increasing the mechanical stimulation of this organ (Hetland and Svihus, 2001) and is extensively ground. Increased retention time in the gizzard may increase nutrient digestibility through the provision of more time for the secretion of hydrochloric acid (González-Alvarado et al., 2008; Svihus, 2011) and pepsin (Svihus, 2011), and by increasing gastric refluxes that serve to re-expose the digesta to pepsin (González-Alvarado et al., 2008). Longer retention time may potentially improve the efficacy of exogenous enzymes (Svihus, 2010) through facilitating the mixing of the feed with added enzymes (GonzálezAlvarado et al., 2008).

\section{Effect of feed form on gut morphology and microbiota profile}

Relatively few studies have been reported on the effect of feed form on the intestinal morphology in broiler chickens. Dahlke et al. (2003) found that pelleted diets increased the number of duodenal villi as compared with mash diets. Greater villus height and crypt depth in both the duodenum and jejunum of pellet-fed birds compared to mash-fed birds were also observed by Amerah et al. (2007b). Zang et al. (2009) reported an increase in villus height and villus height to crypt depth ratio in the small intestinal mucosa of broiler chickens fed pelleted diets compared with those given mash diets, with no effect on crypt depth. These findings might be considered as a general response of the digestive and absorptive capacity to the greater load of nutrients in pellet-fed birds. Higher villus height may increase the absorptive area and subsequently the transport of the nutrients at the villus surface (Cera et al., 1988). Higher crypt depth is an indication of increased turnover rate of intestinal mucosa, which in turn increases the maintenance requirement (Zang et al., 2009).

Since the intestinal microbiota profile competes for nutrients with the host and nutrient absorption mainly takes place in the small intestine, the species, numbers and activity of bacteria in this segment are of critical importance. In the small intestine of poultry, the major bacterial species are lactic acid-producing bacteria, especially Lactobacilli spp. (Barnes, 1972; Engberg et al., 2002). These bacteria are usually considered to offer health benefits for the host, as they prevent colonisation of pathogens bacteria such as E. coli and Salmonella spp. However, Lactobacilli spp. that reside in the small intestine seem to be responsible for deconjugation of bile salts (Feighner and Dashkevicz, 1987), which may reduce the digestion of lipids (Smits et al., 1998). In addition to Lactobacilli spp., other commensal bacteria, including Enterococci, Bifidobacteria, Clostridium and Bacteroides spp., also catalyse bile acid deconjugation (Masuda, 1981; Klaver and van der Meer, 1993; Smits et al., 1998). The microbiota profile and activity in the broiler GIT has shown to be influenced by the physical form of feed. Engberg et al. (2002) reported that pellet-fed birds had lower counts of Lactobacilli spp. and C. perfringens and higher counts of Coliform and Enterococci spp. in the ileum compared to mash-fed birds. Undigested fine particles in pelleted diets can enter the caeca and become available for microbial fermentation. Microbial fermentation in terms of volatile fatty acid concentrations was found to be lower in the caeca of mash fed birds. Unfortunately data on the effect of feed form and cereal type on gut microbiota profile are scanty and more research is warranted in this area. 


\section{Conclusions}

Optimum functionality of GIT in broilers is essential to enhance performance. Broilers appear to have the ability to adjust development of their GIT and digestive functions according to diet structure. In particular, particle size and feed form have major influence on gizzard development. Feeding birds with coarsely ground particles may have an advantage, since this strategy stimulates gastric functions, including secretion of hydrochloric acid, while increases the retention time of feed in the upper GIT.

It can be concluded that, although pelleting reduces particle size and can shorten the retention time in the gizzard as a consequence of reduced gizzard size, it seems that beneficial influence of coarse particles may still exist after pelleting, which would be preferable because of energy savings. However, it should be noted that the grain hardness and type of cereal used in the diet might have important effect. The current published data clearly highlights the need for well-planned studies to evaluate the effect of cereal type, feed form and particle size and their interactions on gut morphology and microbiota profile.

\section{References}

ABDOLLAHI, M.R., RAVINDRAN, V., WESTER, T.J., RAVINDRAN, G. and THOMAS, D.V. (2011) Influence of feed form and conditioning temperature on performance, apparent metabolisable energy and ileal digestibility of starch and nitrogen in broiler starters fed wheat-based diet. Animal Feed Science and Technology 168: 88-99.

ABDOLLAHI, M.R., RAVINDRAN, V. and SVIHUS, B. ( 2013a) Influence of grain type and feed form on performance, apparent metabolisable energy and ileal digestibility of nitrogen, starch, fat, calcium and phosphorus in broiler starters. Animal Feed Science and Technology 186: 193-203.

ABDOLLAHI, M.R., RAVINDRAN, V. and SVIHUS, B. (2013b) Pelleting of broiler diets: an overview with emphasis on pellet quality and nutritional value. Animal Feed Science and Technology 179: 1-23.

ABDOLLAHI, M.R., RAVINDRAN, V. and SVIHUS, B. (2014) Influence of feed form on growth performance, ileal nutrient digestibility, and energy utilisation in broiler starters fed a sorghum-based diet. Livestock Science 165: 80-86.

AGAH, M.J. and NOROLLAHI, H. (2008) Effect of feed form and duration time in growing period on broilers performance. International Journal of Poultry Science 7: 1074-1077.

AMERAH, A. and RAVINDRAN, V. (2009) Influence of particle size and microbial phytase supplementation on the performance, nutrient utilisation and digestive tract parameters of broiler starters. Animal Production Science 49: 704-710.

AMERAH, A.M., RAVINDRAN, V. and LENTLE, R.G. (2007a) Feed particle size: Implications on the digestion and performance in poultry. World's Poultry Science Journal 63: 439-451.

AMERAH, A.M., RAVINDRAN, V., LENTLE, R.G. and THOMAS, D.G. (2007b) Influence of feed particle size and feed form on the performance, energy utilisation, digestive tract development, and digesta parameters of broiler starters. Poultry Science 86: 2615-2623.

AMERAH, A.M., RAVINDRAN, V., LENTLE, R.G. and THOMAS, D.G. (2008a) Influence of feed particle size on the performance, energy utilisation, digestive tract development, and digesta parameters of broiler starters fed wheat- and corn-based diets. Poultry Science 87: 2320-2328.

AMERAH, A.M., RAVINDRAN, V., LENTLE, R.G. and THOMAS, D.G. (2008b) Influence of particle size and xylanase supplementation on the performance, energy utilisation, digestive tract parameters and digesta viscosity of broiler starters. British Poultry Science 49: 455-462.

BARNES, E.M. (1972) The avian intestinal flora with particular reference to the possible ecological significance of the cecal anaerobic bacteria. The American Journal of Clinical Nutrition 25: 1475-1479.

BEHNKE, K.C. (2001) Factors influencing pellet quality. Feed Technology 5: 19-22.

BJERRUM, L., PEDERSEN, K. and ENGBERG, R.M. (2005) The influence of whole wheat feeding on Salmonella infection and gut flora composition in broilers. Avian Disease 49: 9-15.

CERA, K.R., MAHAN, D.C. and CROSS, R.F. (1988) Effect of age, weaning and postweaning diet on small intestinal growth and jejunal morphology in young swine. Journal of Animal Science 66: 574-584.

CHARBENEAU, R.A. and ROBERSON, K.D. (2004) Effect of corn and soybean meal particle size on phosphorus use in turkey poults. Journal of Applied Poultry Research 13: 302-310. 
CHEWNING, C.G., STARK, C.R. and BRAKE, J. (2012) Effects of particle size and feed form on broiler performance. Journal of Applied Poultry Research 21: 830-837.

CUMMING, R.B. (1994) Opportunities for whole grain feeding. In: Proceedings 9th European poultry conference, Vol. II. (Worlds Poultry Science Association: Glasgow, UK), pp. 219-222.

DAHLKE, F., RIBEIRO, A.M.L., KESSLER, A.M., LIMA, A.R. and MAIORKA, A. (2003) Effect of corn particle size and physical form of the diet on the gastrointestinal structures of broiler chickens. Brazilian Journal of Poultry Science 5: 61-67.

DUKE, G.E. (1982) Gastrointestinal motility and its regulation. Poultry Science 61: 1245-1256.

DUKE, G.E. (1994) Anatomy and physiology of the digestive system in fowl. In: Proceedings of the 21st Annual Carolina Poultry Nutrition Conference, Charlotte, NC, pp. 46-49.

ENGBERG, R.M., HEDEMANN, M.S. and JENSEN, B.B. (2002) The influence of grinding and pelleting of feed on the microbial composition and activity in the digestive tract of broiler chickens. British Poultry Science 43: 569-579.

ENGBERG, R.M., HEDEMANN, M.S., STEENFELDT, S. and JENSEN, B.B. (2004) Influence of whole wheat and xylanase on broiler performance and microbial composition and activity in the digestive tract. Poultry Science 83: 925-938.

FEIGHNER, S.D. and DASHKEVICZ, M.P. (1987) Subtherapeutic levels of antibiotics in poultry feeds and their effects on weight gain, feed efficiency, and bacterial cholyltaurine hydrolase activity. Applied and Environmental Microbiology 53: 331-336

FERKET, P.R. (2000) Feeding whole grains to poultry improves gut health. Feedstuffs 4: 12-14.

FERKET, P.R. and GERNAT, A.G. (2006) Factors that affect feed intake of meat birds: A review. International Journal of Poultry Science 5: 905-911.

FRIKHA, M., SAFAA, H.M., SERRANO, M.P., ARBE, X. and MATEOS, G.G. (2009) Influence of the main cereal and feed form of the diet on performance and digestive tract traits of brown-egg laying pullets. Poultry Science 88: 994-1002.

GABRIEL, I., MALLET, S. and LECONTE, M. (2003a) Differences in the digestive tract characteristics of broiler chickens fed on complete pelleted diet or whole wheat added to pelleted protein concentrate. British Poultry Science 44: 283-290.

GABRIEL, I., MALLET, S., LECONTE, M., FORT, G. and NACIRI, M. (2003b) Effects of whole wheat feeding on the development of coccidial infection in broiler chickens. Poultry Science 82: 1668-1676.

GABRIEL, I., MALLET, S., LECONTE, M., FORT, G. and NACIRI, M. (2006) Effects of whole wheat feeding on the development of coccidial infection in broiler chickens until market-age. Animal Feed Science and Technology 129: 279-303.

GONZÁLEZ-ALVARADO, J.M., JIMENEZ-MORENO, E., VALENCIA, D.G., LAZARO, R. and MATEOS, G.G. (2008) Effects of fiber source and heat processing of the cereal on the development and $\mathrm{pH}$ of the gastrointestinal tract of broilers fed diets based on corn or rice. Poultry Science 87: 1779-1795.

GARCiA, V., GOMEZ, J., MIGNON-GRASTEAU, S., SElliER, N. and CARRÉ, B. (2007) Effects of xylanase and antibiotic supplementations on the nutritional utilization of a wheat diet in growing chicks from genetic $\mathrm{D}^{+}$and $\mathrm{D}^{-}$lines selected for divergent digestion efficiency. Animal 1: 1435-1442.

HETLAND, H., CHOCT, M. and SVIHUS, B. (2004) Role of insoluble non-starch polysaccharides in poultry nutrition. World's Poultry Science Journal 60: 415-422.

HETLAND, H. and SVIHUS, B. (2001) Effect of oat hulls on performance, gut capacity and feed passing time in broiler chickens. British Poultry Science 42: 354-361.

HETLAND, H., SVIHUS, B. and OLAISEN, V. (2002) Effect of feeding whole cereals on performance, starch digestibility and duodenal particle size distribution in broiler chickens. British Poultry Science 43: 416423.

HILL, K.J. (1971) The physiology of digestion, in: BELL, D.J. \& FREEMAN, B.M. (Eds) Physiology and Biochemistry of the Domestic Fowl, pp. 25-49 (Academic Press, London, Great Britain).

HUANG, D.S., LI, D.F., XING, J.J., MA, Y.X., LI, Z.J. and LV, S.Q. (2006) Effects of feed particle size and feed form on survival of Salmonella typhimurium in the alimentary tract and cecal S. typhimurium reduction in growing broilers. Poultry Science 85: 831-836.

JACOBS, C.M., UTTERBACK, P.L. and PARSONS, C.M. (2010) Effect of corn particle size on growth performance and nutrient utilisation in young chicks. Poultry Science 89: 539-544.

JIMÉNEZ-MORENO, E., FRIKHA, M., DE COCA-SINOVA, A., LÁZARO, R.P., and MATEOS, G.G. (2013) Oat hulls and sugar beet pulp in diets for broilers. 2. Effects on the development of the gastrointestinal tract and on the structure of the jejunal mucosa. Animal Feed Science and Technology 182: 44-52.

JIMÉNEZ-MORENO, E., GONZÁLEZ-ALVARADO, J.M., DE COCA-SINOVA, A., LÁZARO, R. and MATEOS, G.G. (2009) Effects of source of fibre on the development and pH of the gastrointestinal tract of broilers. Animal Feed Science and Technology 154: 93-101.

KARASAWA, Y. (1999) Significant role of the nitrogen recycling system through the ceca occurs in proteindepleted chickens. Journal of Experimental Zoology 283: 418-425. 
KILBURN, J. and EDWARDS, H.M. Jr (2004) The effect of particle size of commercial soybean meal on performance and nutrient utilisation of broiler chicks. Poultry Science 83: 428-432.

KLAVER, F.A.M. and VAN DER MEER, R. (1993) The assumed assimilation of cholesterol by lactobacilli and bifidobacterium bifidum is due to their bile salt-deconjugation activity. Applied and Environmental Microbiology 59: 1120-1124.

LIU, Y.H., PIAO, X.S., OU, D.Y., CAO, Y.H., HUANG, D.S. and LI, D.F. (2006) Effects of particle size and physical form of diets on mast cell numbers, histamine, and stem cell factor concentration in the small intestine of broiler chickens. Poultry Science 85: 2149-2155.

LIU, S.Y., TRUONG, H.H. and SELLE, P.H. (2015) Whole-grain feeding for chicken-meat production: possible mechanisms driving enhanced energy utilisation and feed conversion. Animal Production Science 55: $559-572$.

MAISONNIER, S., GOMEZ, J. and CARRÉ, B. (2001) Nutrient digestibility and intestinal viscosities in broiler chickens fed on wheat diets, as compared to maize diets with added guar gum. British Poultry Science 42: $102-110$.

MASUDA, N. (1981) Deconjugation of bile salts by Bacteroides and Clostridium. Microbiology and Immunology 25: 1-11.

MIRGHELENJ, S.A. and GOLIAN, A. (2009) Effects of feed form on development of digestive tract, performance and carcass traits of broiler chickens. Journal of Animal and Veterinary Advances 8: 1911-1915.

MOORE, S.J. (1999) Food breakdown in an avian herbivore: Who needs teeth? Australian Journal of Zoology 47: 625-632.

NADERINEJAD, S., ZAEFARIAN, F., ABDOLLAHI, M.R., HASSANABADI, A., KERMANSHAHI, H. and RAVINDRAN, V. (2015) Influence of feed form and particle size on the performance and nutrient utilisation of broiler starters fed maize-based diets. Proceedings of the Australian Poultry Science Symposium 26: 141-144.

NADERINEJAD, S., ZAEFARIAN, F., ABDOLLAHI, M.R., HASSANABADI, A., KERMANSHAHI, H. and RAVINDRAN, V. (2016) Influence of feed form and particle size on performance, nutrient utilisation, and gastro intestinal tract development and morphometry in broiler starters fed maize-based diets. Animal Feed Science and Technology 215: 92-104.

NIR, I. and PTICHI, I. (2001) Feed particle size and hardness: Influence on performance, nutritional, behavioural and metabolic aspects. Pages 157-186 in Proc. 1st World Feed Conf., Utrecht, the Netherlands. Wageningen Press, Wageningen, the Netherlands.

NIR, I., HILLEL, R., SHEFET, G. and NITSAN, Z. (1994a) Effect of grain particle size on performance. 2. Grain texture interactions. Poultry Science 73: 781-791.

NIR, I., TWINA, Y., GROSSMAN, E. and NITSAN, Z. (1994b) Quantitative effects of pelleting on performance, gastrointestinal tract and behaviour of meat-type chickens. British Poultry Science 35: 589-602.

NIR, I., HILLEL, R., PTICHI, I. and SHEFET, G. (1995) Effect of particle size on performance. 3. Grinding pelleting interactions. Poultry Science 74: 771-783.

O'DELL, B.L., NEWBERNE, P.M. and SAVAGE, J.E. (1959) An abnormality of the proventriculus caused by feed texture. Poultry Science 38: 296-301.

PACHECO, W.J., STARK, C.R., FERKET, P.R. and BRAKE, J. (2013) Evaluation of soybean meal source and particle size on broiler performance, nutrient digestibility, and gizzard development. Poultry Science $\mathbf{9 2}$ : 2914-2922.

PARSONS, A.S., BUCHANAN, N.P., BLEMINGS, K.P., WILSON, M.E. and MORITZ, J.S. (2006) Effect of corn particle size and pellet texture on broiler performance in the growing phase. Journal of Applied Poultry Research 15: 245-255.

PÉRON, A., BASTIANELlI, D., OURY, F.X., GOMEZ, J. and CARRÉ, B. (2005) Effects of food deprivation and particle size of ground wheat on digestibility of food components in broilers fed on a pelleted diet. British Poultry Science 46: 223-230.

PRESTON, C.M., MCCRACKEN, K.J. and MCALLISTER, A. (2000) Effect of diet form and enzyme supplementation on growth, efficiency and energy utilisation of wheat-based diets for broilers. British Poultry Science 41: 324-331.

RAVINDRAN, V. (2013) Feed enzymes: the science, the practice and the metabolic realities. Journal of Applied Poultry Research 22: 636-644.

ROUGIÈre, N., GOMEZ, J., MIGNON-GRASTEAU, S. and CARRÉ, B. (2009) Effects of diet particle size on digestive parameters in $\mathrm{D}^{+}$and $\mathrm{D}^{-}$genetic chicken lines selected for divergent digestion efficiency. Poultry Science 88: 1206-1215.

SACRANIE, A. (2006) Dietary and age regulation of antiperistalsis in broiler chickens. MS thesis. University of New England, Biddeford, ME.

SACRANIE, A., SVIHUS, B., DENSTADLI, V., MOEN, B., IJI, A. and CHOCT, M. (2012) The effect of insoluble fibre and intermittent feeding on gizzard development, gut motility, and performance of broiler chickens. Poultry Science 91: 693-700. 
SANTOS, F.B.O., SHELdON, B.W., SANTOS, A.A. Jr and FERKET, P.R. (2008) Influence of housing system, grain type, and particle size on Salmonella colonization and shedding of broilers fed triticale or corn soybean meal diets. Poultry Science 87: 405-420.

SELLE, P.H. and RAVINDRAN, V. (2007) Microbial phytase in poultry nutrition. Animal Feed Science and Technology 135: 1-41.

SINGH, Y., RAVINDRAN, V., WESTER, T.J., MOLAN, A.L. and RAVINDRAN, G. (2014) Influence of feeding coarse corn on performance, nutrient utilisation, digestive tract measurements, carcass characteristics, and cecal microflora counts of broilers. Poultry Science 93: 607-616.

SMITS, C.H.M., VELDMAN, A., VERKADE, H.J. and BEYNEN, A.C. (1998) The inhibitory effect of carboxymethylcellulose with high viscosity on lipid absorption in broiler chickens coincides with reduced bile salt concentration and raised microbial numbers in the small intestine. Poultry Science 77: 1534-1539.

SVIHUS, B. (2010) Diet composition and processing adjustments to cover the bird's need for structural components. Proceedings of the $8^{\text {th }}$ Annual Mid-Atlantic Nutrition Conference, University of Maryland, College Park, MD. pp 99-107.

SVIHUS, B. (2011) The gizzard: function, influence of diet structure and effects on nutrient availability. World's Poultry Science Journal 67: 207-223.

SVIHUS, B. (2014) Function of the digestive system. Journal of Applied Poultry Research 23: 1-9.

SVIHUS, B., CHOCT, M. and CLASSEN, H.L. (2013) Function and nutritional roles of the avian caeca: a review. World's Poultry Science Journal 69: 249-264.

SVIHUS, B., HETLAND, H., CHOCT, M. and SUNDBY, F. (2002) Passage rate through the anterior digestive tract of broiler chickens fed on diets with ground and whole wheat. British Poultry Science 43: 662-668.

SVIHUS, B., JUVIK, E., HETLAND, H. and KROGDAHL, A. (2004a) Causes for improvement in nutritive value of broiler chicken diets with whole wheat instead of ground wheat. British Poultry Science 45: 55-60.

SVIHUS, B., KLØVSTAD, K.H., PEREZ, V., ZIMONJA, O., SAHLSTROM, S., SCHULLER, R.B., JEKSRUD, W.K. and PRESTLØKKEN, E. (2004b) Physical and nutritional effects of pelleting of broiler chicken diets made from wheat ground to different coarsenesses by the use of roller mill and hammer mill. Animal Feed Science Technology 117: 281-293.

XU, Y., STARK, C.R., FERKET, P.R., WILliAMS, C.M., AUTTAWONG, S. and BRAKE, J. (2015a) Effects of dietary coarsely ground corn and litter type on broiler live performance, litter characteristics, gastrointestinal tract development, apparent ileal digestibility of energy and nitrogen, and intestinal morphology. Poultry Science 94: 353-361.

XU, Y., STARK, C.R., FERKET, P.R., WILlIAMS, C.M., NUSAIRAT, B. and BRAKE, J. (2015b) Evaluation of litter type and dietary coarse ground corn inclusion on broiler live performance, gastrointestinal tract development, and litter characteristics. Poultry Science 94: 362-370.

XU, Y., STARK, C.R., FERKET, P.R., WILLIAMS, C.M. and BRAKE, J. (2015c) Effects of feed form and dietary coarse ground corn on broiler live performance, body weight uniformity, relative gizzard weight, excreta nitrogen, and particle size preference behaviors. Poultry Science 94: 1549-1556.

ZANG, J.J., PIAO, X.S., HUANG, D.S., WANG, J.J., MA, X. and MA, Y.X. (2009) Effects of feed particle size and feed form on growth performance, nutrient metabolisability and intestinal morphology in broiler chickens. Asian-Australian Journal of Animal Sciences 22: 107-112. 